\title{
ALLOYING EFFECTS ON MICROSTRUCTURAL STABILITY AND $\gamma$ ' PHASE NANO-HARDNESS IN Co-Al-W-Ta-Ti-BASE SUPERALLOYS
}

\author{
H.J. Zhou ${ }^{1}$, W.D. Li ${ }^{1}$, F. Xue ${ }^{1}$, L. Zhang ${ }^{2}$, X.H. Qu ${ }^{1,2}$ and Q. Feng ${ }^{1}$ \\ ${ }^{1}$ State Key Laboratory for Advanced Metals and Materials, University of Science and Technology Beijing, Beijing, 100083, China \\ ${ }^{2}$ Institute for Advanced Materials and Technology, University of Science and Technology Beijing, Beijing, 100083, China
}

Keywords: Co-base, alloying elements, phase equilibria, microstructural stability, nano-hardness

\begin{abstract}
In previous work, Co-Al-W-Ta-Ti quinary alloys were found to show excellent creep resistance and microstructural stability at higher temperature as well as high $\gamma^{\prime}$ solvus temperature. In the current research, alloying effects on microstructural evolution, phase equilibria at $1000 \sim 1100{ }^{\circ} \mathrm{C}$ as well as $\gamma^{\prime}$ phase nanohardness were investigated in Co-Al-W-Ta-Ti-X alloys $(\mathrm{X}=\mathrm{Cr}$, $\mathrm{Mo}, \mathrm{Nb}, \mathrm{Ni}$ and $\mathrm{V}$ ). Phase diagram calculations were also performed using Pandat ${ }^{\mathrm{TM}^{*}}$. It is suggested that $\mathrm{Ni}$ and $\mathrm{V}$ additions increased $\gamma^{\prime}$ solvus temperature, while $\mathrm{Cr}$, Mo and $\mathrm{Nb}$ additions presented a negative effect. The composition of the baseline alloy is located in the $\gamma+\gamma^{\prime}$ two phase region at $1000 \sim$ $1050{ }^{\circ} \mathrm{C}$ but lies in the $\gamma+\gamma^{\prime}+\chi+\beta$ phase region at $1100{ }^{\circ} \mathrm{C}$. Additions of $\mathrm{Cr}, \mathrm{Nb}, \mathrm{V}$ and $\mathrm{Mo}$ strongly promoted the precipitation of $\chi$ phase at $1100{ }^{\circ} \mathrm{C}$, while $\beta$ phase co-existed in alloys containing $\mathrm{Cr}$ and $\mathrm{V}$, respectively. Ni addition enlarged the $\gamma+\gamma^{\prime}$ two phase region obviously in the investigated temperature range. The above experimental results generally suggested that $\gamma+\gamma^{\prime}$ two phase region is smaller than the calculated phase equilibria. Nano indentation measurements showed that alloying additions increased $\gamma^{\prime}$ nano-hardness $\left(\gamma^{\prime}\right.$ hardness $)$ in the following order: $\mathrm{V}>\mathrm{Nb}>\mathrm{Mo} \approx \mathrm{Ni}$, while $\mathrm{Cr}$ addition showed the negative effect distinctly. The current study is helpful to understand phase equilibria and microstructure in Co-Al-W-TaTi-base alloys and further develop multi-component $\gamma^{\prime}$ strengthened Co-base superalloys.
\end{abstract}

\section{Introduction}

Due to excellent mechanical properties and microstructural stability, Ni-base superalloys are common materials for high temperature applications such as gas turbines in aerospace and power-generation industries $[1,2]$. Co-base superalloys can exhibit better hot corrosion, oxidation and wear resistance, but lack in effective precipitation strengthening in comparison with $\gamma$-strengthened Ni-base superalloys [3]. Therefore, they have lower high-temperature capability and relatively limited application in gas turbine industries. In 2006, Sato et al. identified Co-Al-W base superalloys with $\gamma$-strengthening showing high temperature strength, comparable to that of Ni-base superalloys, as well as greater strength than that of traditional Cobase superalloys at high temperature [4]. The influence of alloying elements, such as $\mathrm{Ta}, \mathrm{Ti}, \mathrm{Nb}, \mathrm{V}$ and $\mathrm{Mo}$, on microstructural stability in Co-base ternary alloys were studied to further develop this new class of superalloys as promising structural materials [5-11]. Our previous research revealed a pronounced increase of $\gamma^{\prime}$ solvus temperature by $\mathrm{Ti}$ and $\mathrm{Ta}$ additions. Moreover, a Co-Al-W-Ta-Ti alloy with excellent microstructural stability and mechanical properties was developed based on fundamental studies on ternary and

\footnotetext{
* Pandat $^{\mathrm{TM}}$ is a registered trademark of CompuTherm LLC
}

quaternary alloys [12-14]. Besides $\mathrm{Ta}$ and $\mathrm{Ti}$, other studies indicated that $\mathrm{V}, \mathrm{Ti}, \mathrm{Nb}, \mathrm{Mo}, \mathrm{Cr}$ and $\mathrm{Ni}$ additions also stabilized $\gamma^{\prime}$ phase with higher $\gamma^{\prime}$ solvus temperature, but $\mathrm{Re}$ and $\mathrm{Fe}$ additions showed a negative effect on $\gamma^{\prime}$ solvus temperature [4, 9$11,15]$. Moreover, the $\gamma^{\prime}$ volume fraction and $\gamma / \gamma^{\prime}$ lattice misfit, which is correlated with $\gamma^{\prime}$ morphology, have considerable influence on creep resistance of Ni-base superalloys [1,3]. It was reported that $\gamma^{\prime}$ volume fraction was increased by $\mathrm{Ti}, \mathrm{Nb}$, Ta and $\mathrm{V}$ additions, but decreased with the additions of $\mathrm{Ni}, \mathrm{Fe}, \mathrm{Cr}$, Mo, and $\mathrm{Re}$ in Co-Al-W-base alloys [9, 11, 15]. However, these studies were quite limited and the effects of alloying additions on $\gamma^{\prime}$ volume fraction and morphology under long term heat treatment were rarely reported.

Phase equilibria and microstructural stability at high temperature are quite essential for superalloy development, since deleterious phases such as topological-close-packed (TCP) phases may precipitate after long term thermal exposure. According to the Co-rich corner of Co-Al, Co-W and Co-Al-W phase diagrams, CoAl-base $\beta$ phase, $\mathrm{Co}_{7} \mathrm{~W}_{6}$-base $\mu$ phase and $\mathrm{Co}_{3} \mathrm{~W}$-base $\chi$ phase may exist in Co-Al-W-base alloys at high temperature, especially if the $\gamma+\gamma^{\prime}$ two-phase region is too narrow [4]. Previous reports indicated that these secondary phases were present in alloys with relatively high content of refractory alloying elements (W, Mo, $\mathrm{Nb}$ and $\mathrm{Ta}$ ), and they may probably serve as detrimental precipitates due to their plate-like morphology and refractory-rich compositions $[6,10]$. It is necessary to understand alloying effects on phase equilibria for desired microstructural stability. However, there have been limited systematic studies focusing on the influence of alloying additions on phase equilibria and microstructural stability in Co-Al-W-Ta-Ti-base alloys at the temperature range of $1000 \sim 1100{ }^{\circ} \mathrm{C}$. On the other hand, the traditional method of alloy design with lots of compositions and tests is not an efficient way to design new alloys. Pandat software is an integrated computational tool developed on the basis of the CALPHAD (CALculation of PHAse Diagram) approach for multi-component phase diagram calculation and materials property simulation. Importantly, it is the only software to utilize a novel Co-base alloys thermodynamic database (PanCo 2016) up to now.

Besides microstructural stability and volume fraction of $\gamma^{\prime}$ phase in Co-base alloys, the $\gamma^{\prime}$ strength and its resistance against strain are also essential for superalloys, since the $\gamma^{\prime}$ phase is one of the major strengthening phase in superalloys. The hardness of $\gamma^{\prime}$ phase in Ni-base [16,17] and Co-base [18] superalloys has been studied by using atomic force microscopy (AFM) method. A recent study indicated that additions of $\mathrm{Ta}$ and $\mathrm{Ti}$ increased the hardness of $\gamma^{\prime}$ phase in Co-Al-W-base alloys, which can be ascribed to the substitution of $\mathrm{Al}$ and $\mathrm{W}$ atoms by Ta and $\mathrm{Ti}$ [20]. Moreover, systematic research of other alloying effects on $\gamma^{\prime}$ hardness have not yet been undertaken. 
In the current study, Co-Al-W-Ta-Ti-base alloys containing different alloying elements were investigated. Of particular interest was alloying effects on $\gamma^{\prime}$ solvus temperature, phase equilibria and microstructural evolution as well as $\gamma^{\prime}$ phase hardness after aging treatment in the temperature range of $1000 \sim$ $1100{ }^{\circ} \mathrm{C}$

\section{Experimental}

The nominal compositions and abbreviated names of the experimental alloys are listed in Table I. The baseline alloy was selected due to its desired microstructural stability according to our previous study $[13,14]$. Mo, $\mathrm{Nb}$ and $\mathrm{V}$, as $\gamma^{\prime}$ forming elements in Co-base superalloys, oxidation/corrosion resistant element $\mathrm{Cr}$ as well as $\gamma+\gamma^{\prime}$ region expanding element Ni were selected in the current study.

Table I. Nominal Compositions of the Experimental Alloys, at.\%

\begin{tabular}{|c|c|c|c|c|c|c|c|c|c|c|}
\hline Utilised & \multicolumn{10}{|c|}{ Nominal composition } \\
\cline { 2 - 11 } & Co & Al & W & Ti & Ta & Cr & Mo & Nb & V & Ni \\
\hline Baseline & bal & 7 & 7 & 4 & 2 & - & - & - & - & - \\
$4 \mathrm{Cr}$ & bal & 7 & 7 & 4 & 2 & 4 & - & - & - & - \\
$1 \mathrm{Mo}$ & bal & 7 & 6 & 4 & 2 & - & 1 & - & - & - \\
$1 \mathrm{Nb}$ & bal & 7 & 6 & 4 & 2 & - & - & 1 & - & - \\
$1 \mathrm{~V}$ & bal & 7 & 7 & 4 & 2 & - & - & - & 1 & \\
$20 \mathrm{Ni}$ & bal & 7 & 7 & 4 & 2 & - & - & - & - & 20 \\
\hline
\end{tabular}

Experimental alloys, $700 \mathrm{~g}$ in weight and $75 \mathrm{~mm}$ in diameter, were melted from high-purity metals in a vacuum induction furnace. The sectioned samples were placed in quartz tubes backfilled with $\mathrm{Ar}$ gas before heat treatment. They were solution treated at $1250{ }^{\circ} \mathrm{C}$ for $24 \mathrm{~h}$ following by air cooling and aging in the temperature range of $1000{ }^{\circ} \mathrm{C}$ and $1100{ }^{\circ} \mathrm{C}$ for times of $50 \mathrm{~h}$ and $1000 \mathrm{~h}$ to investigate the influence of alloying elements on microstructural stability.

Cylindrical samples for differential scanning calorimetry (DSC) experiments with the mass ranging from 60 to $90 \mathrm{mg}$ were utilized. DSC was performed using a NETZSCH STA 449C thermal analyzer under high purity argon flow. The $\gamma^{\prime}$ solvus temperatures of experimental alloys were determined based on the endothermic peak of $\gamma^{\prime}$ phase, and the solidus temperatures were defined as the intersection temperature of the baseline and the tangent line with the maximum slope at the endothermic liquidus peak, while the heating rate was $10{ }^{\circ} \mathrm{C} / \mathrm{min}$.

Metallurgical samples were prepared using standard metallographic techniques and etched in a reagent of $33 \% \mathrm{HNO}_{3}$ and $67 \% \mathrm{CH}_{3} \mathrm{OH}$ (by volume). Microstructural observation of heat-treated samples was conducted with a ZEISS SUPRA 55 field-emission scanning electron microscope (FESEM) in secondary electron (SE) and back-scattered electron (BSE) imaging modes. The $\gamma^{\prime}$ volume fraction was measured by the standard point count method [21]. The $\gamma^{\prime}$ size was measured by the average length of diameters at 2 degree intervals and passing through the object's centroid by the Image-Pro 6.0 software. The volume fraction of secondary phases in heat-treated alloys was measured by the Image-Pro 6.0 software in BSE images.

The phase equilibria of Co-base superalloys, which include the system of Co-Al-W, were calculated using the Pandat software. In this method, the phase equilibria of the Co-Al-W-Ti-Ta-X (X
$=\mathrm{Cr}, \mathrm{Mo}, \mathrm{Nb}, \mathrm{Ni}$ ) alloys were studied by the thermodynamic database of the PanCo 2016, while V is not available element in the database. A line calculation was performed for the experimental alloys.

Bulk samples for nano-indentation were aged at $1000{ }^{\circ} \mathrm{C}$ for 1000 $\mathrm{h}$ in order to obtain coarsened $\gamma^{\prime}$ precipitates and to enable separate indentation on the $\gamma^{\prime}$ phase. Nano-indentation was performed with an Agilent Nano Indenter G200 using the continuous stiffness method (CSM) [22]. The indentation head in Berkovich shape was controlled by the displacement. The maximum displacement was $100 \mathrm{~nm}$ with a strain rate of $0.05 \mathrm{~s}^{-1}$ and the thermal drift was less than $0.05 \mathrm{~nm} / \mathrm{s}$. To confirm the measurement on $\gamma^{\prime}$ precipitates only, 20 nano-indentation points, in $5 \times 4$ arrays, were performed on each sample. The schematic of the point arrays and a single nano-indentation point in a $\gamma^{\prime}$ precipitate are shown in Figures 1 (a) and (b), respectively. The elastic modulus and hardness of $\gamma^{\prime}$ phase in experimental alloys were determined by analyzing the load-displacement curves recorded during indentation according to the Oliver-Pharr method [19].

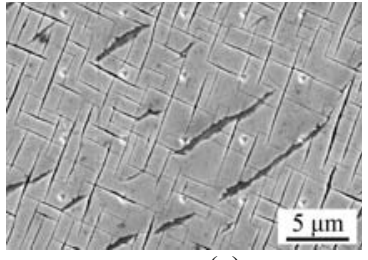

(a)

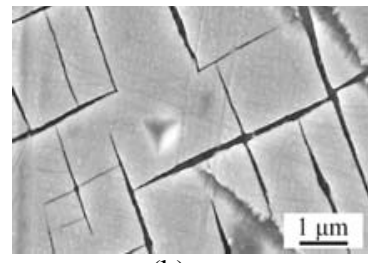

(b)
Figure 1. Schematic of the nano-indentation point arrays (a) and a single nano-indentation point in a $\gamma^{\prime}$ precipitate (b).

\section{Results}

\section{$\gamma^{\prime}$ solvus temperature}

The $\gamma^{\prime}$ solvus temperatures of six experimental alloys are listed in Table II. Compared to the baseline alloy, there is a negative influence of $\mathrm{Nb}$ on $\gamma^{\prime}$ solvus temperature by about $10{ }^{\circ} \mathrm{C}$, although the additions of 4 at.\% $\mathrm{Cr}$ and 1 at.\% Mo decreased $\gamma^{\prime}$ solvus temperatures by $66{ }^{\circ} \mathrm{C}$ and $17{ }^{\circ} \mathrm{C}$, respectively. The addition of 1 at. $\% \mathrm{~V}$ promoted the thermal stability of $\gamma^{\prime}$ phase by only $6{ }^{\circ} \mathrm{C}$, while 20 at.\% $\mathrm{Ni}$ addition showed the most positive effect on $\gamma^{\prime}$ solvus temperature in all experimental alloys, which was $1185^{\circ} \mathrm{C}$. Moreover, additions of Mo and V did not change the solidus temperatures significantly compared to the baseline alloy. The addition of $\mathrm{Cr}$ increased the solidus temperature by 10 ${ }^{\circ} \mathrm{C}$ although the $\mathrm{Nb}$ addition decreased the solidus temperature of the experimental alloys significantly.

Table. II $\gamma^{\prime}$ Solvus and Solidus Temperature of Experimental

\begin{tabular}{|c|c|c|}
\multicolumn{3}{c}{ Alloys, ${ }^{\circ} \mathrm{C}$} \\
\hline Alloys & $\begin{array}{c}\gamma^{\prime} \text { solvus } \\
\text { temperature }\end{array}$ & $\begin{array}{c}\text { solidus } \\
\text { temperature }\end{array}$ \\
\hline Baseline & 1160 & 1313 \\
$4 \mathrm{Cr}$ & 1094 & 1323 \\
$1 \mathrm{Mo}$ & 1143 & 1317 \\
$1 \mathrm{Nb}$ & 1150 & 1285 \\
$1 \mathrm{~V}$ & 1166 & 1312 \\
$20 \mathrm{Ni}$ & 1185 & $>1270^{*}$ \\
\hline
\end{tabular}

* Maximum testing temperature of this measurement 

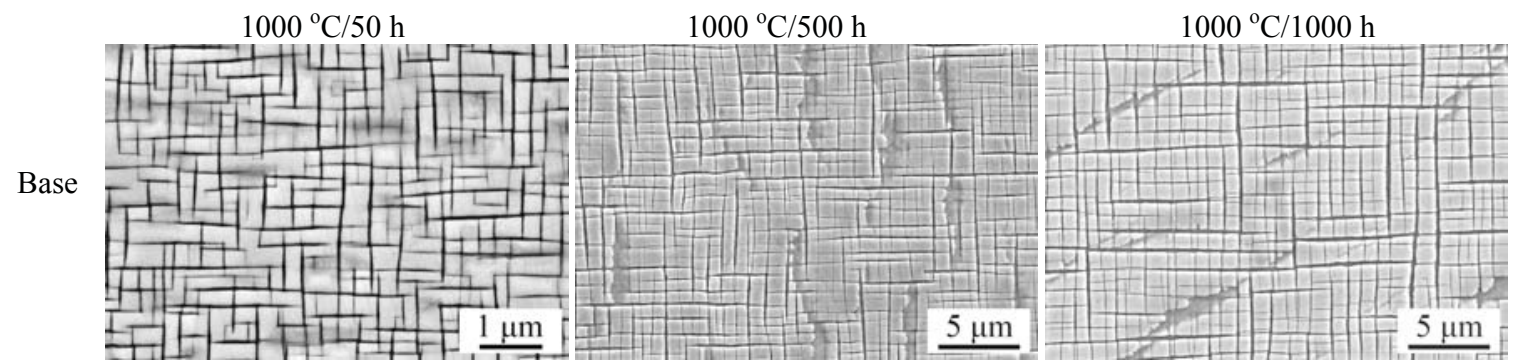

(a1)

(a2)

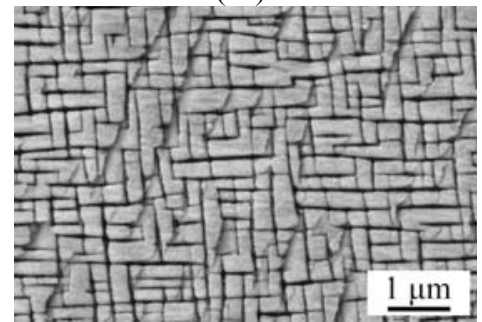

(b1)

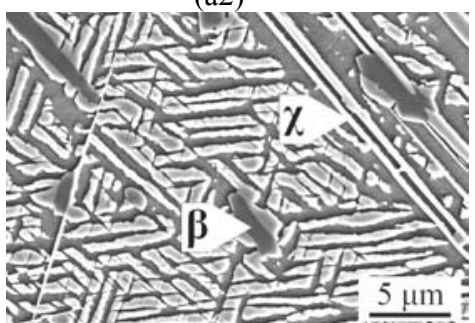

(a3)

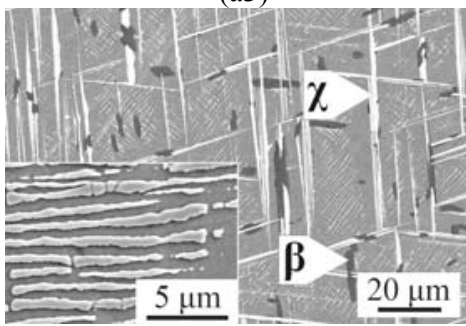

(b2)

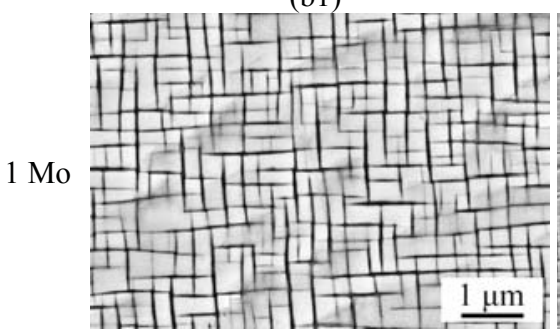

(c1)

$1 \mathrm{Nb}$

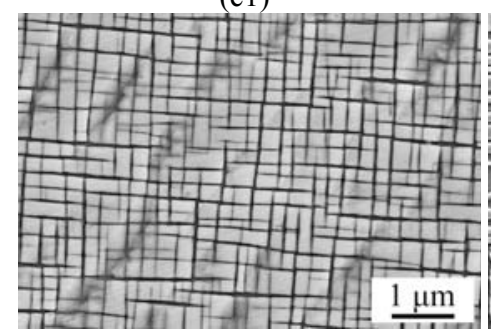

(d1)

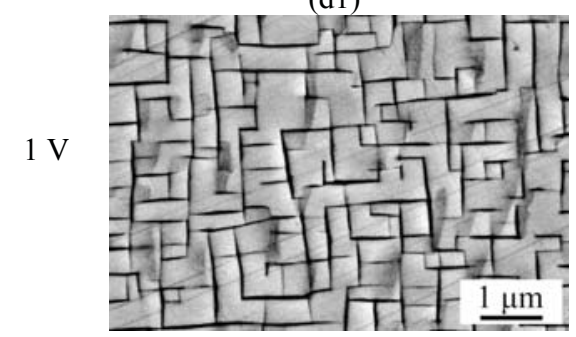

(e1)

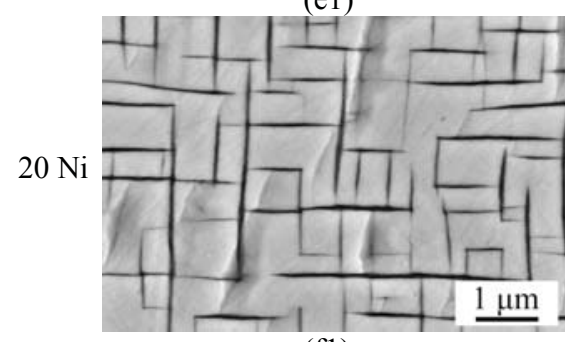

(f1)

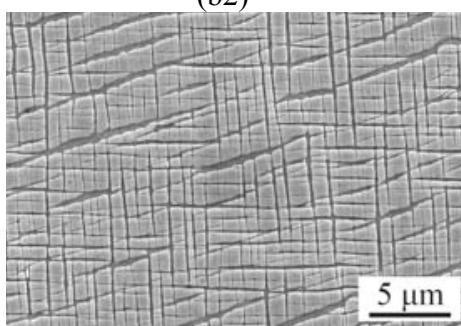

(c2)

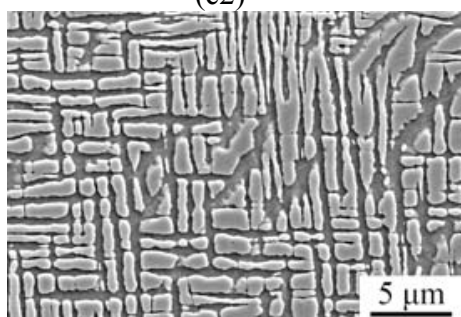

(d2)

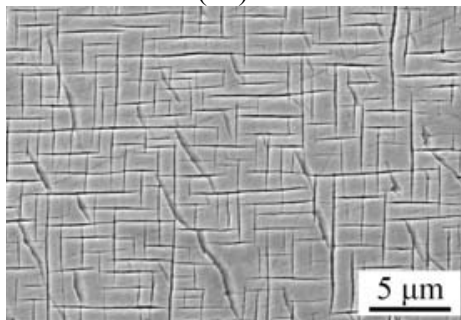

(e2)

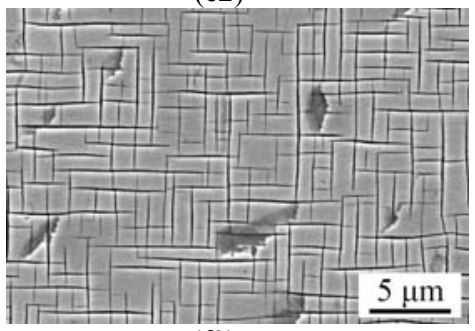

(f2) (b3)

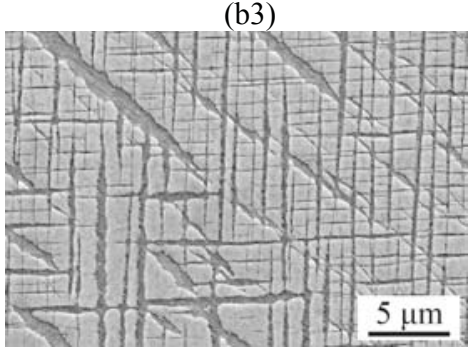

(c3)

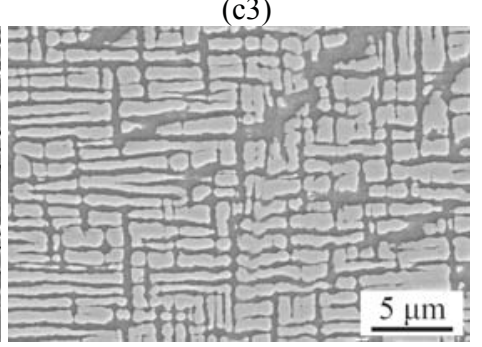

(d3)

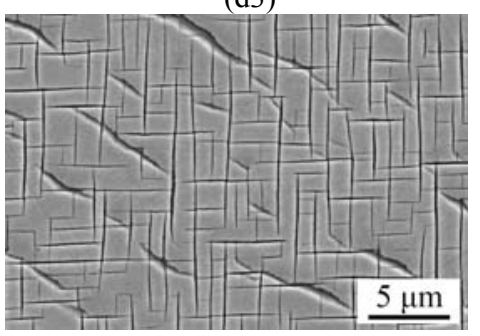

(e3)

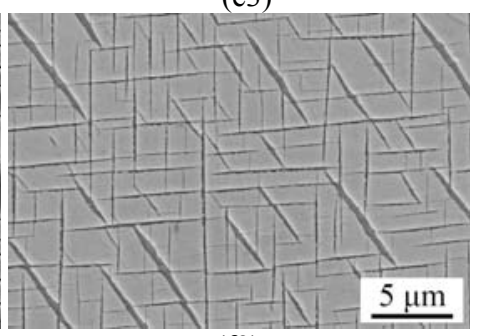

(f3)

Figure 2. Secondary electron images of etched samples showing the typical matrix microstructures of experimental alloys after heat treatment at $1000{ }^{\circ} \mathrm{C}$ for $50 \sim 1000 \mathrm{~h}$. 
Table III. Computational (Cal.) and Experimental Volume Fractions of Various Phases in Experimental Alloys after Aging at $1000 \sim 1100$ ${ }^{\circ} \mathrm{C}$ for $50 \sim 1000 \mathrm{~h}, \%$

\begin{tabular}{|c|c|c|c|c|c|c|c|c|c|c|c|c|c|}
\hline \multirow{2}{*}{ Alloy } & \multirow{2}{*}{ phases } & \multicolumn{4}{|c|}{$1000^{\circ} \mathrm{C}$} & \multicolumn{4}{|c|}{$1050^{\circ} \mathrm{C}$} & \multicolumn{4}{|c|}{$1100^{\circ} \mathrm{C}$} \\
\hline & & $50 \mathrm{~h}$ & $500 \mathrm{~h}$ & $1000 \mathrm{~h}$ & Cal. & $50 \mathrm{~h}$ & $500 \mathrm{~h}$ & $1000 \mathrm{~h}$ & Cal. & $50 \mathrm{~h}$ & $500 \mathrm{~h}$ & $1000 \mathrm{~h}$ & Cal. \\
\hline \multirow{3}{*}{ Baseline } & $\gamma^{\prime}$ & 81.3 & 80.0 & 72.5 & 62.5 & 79.5 & 64.2 & 63.2 & 51.8 & 71.2 & 32.9 & 66.5 & 35.5 \\
\hline & $\chi$ & 0 & 0 & 0 & 0 & 0 & 0 & 0 & 0 & 0 & 0 & $<0.5$ & 0 \\
\hline & $\beta$ & 0 & 0 & 0 & 0 & 0 & 0 & 0 & 0 & 0 & 0 & 0 & 0 \\
\hline \multirow{3}{*}{$4 \mathrm{Cr}$} & $\gamma^{\prime}$ & 83.3 & 51.0 & 40.3 & 54.1 & 64.9 & 0 & 0 & 37.7 & 27.7 & 0 & 0 & 13.6 \\
\hline & $\chi$ & 0 & 0 & 10.5 & 0 & $<0.5$ & 7.8 & 14.7 & 0 & 2.4 & 13.4 & 19.9 & 0 \\
\hline & $\beta$ & 0 & 0 & 5.9 & 0 & 3.5 & 6.8 & 6.9 & 0 & 4.8 & 5.2 & 7.3 & 0 \\
\hline \multirow{3}{*}{$1 \mathrm{Mo}$} & $\gamma^{\prime}$ & 86.0 & 77.2 & 61.1 & 57.2 & 79.9 & 60.4 & 54.6 & 43.8 & 65.1 & 0 & 5.1 & 23.8 \\
\hline & $\chi$ & 0 & 0 & 0 & 0 & 0 & $<0.5$ & 1.6 & 0 & 0 & 8.6 & 10.3 & 0 \\
\hline & $\beta$ & 0 & 0 & 0 & 0 & 0 & 0 & 0 & 0 & 0 & $<0.5$ & 0.9 & 0 \\
\hline \multirow{3}{*}{$1 \mathrm{Nb}$} & $\gamma^{\prime}$ & 81.0 & 55.8 & 71.0 & 60.7 & 74.5 & 57.4 & 54.7 & 49.4 & 62.6 & 0 & 0 & 32.5 \\
\hline & $\chi$ & 0 & 0 & 0 & 0 & $<0.5$ & 1.5 & 5.3 & 0 & $<0.5$ & 7.3 & 17.2 & 0 \\
\hline & $\mu$ & 0 & 0 & 0 & 0 & $<0.5$ & $<0.5$ & 0 & 0 & 0 & 4.2 & 6.3 & 0 \\
\hline \multirow{3}{*}{$1 \mathrm{~V}$} & $\gamma^{\prime}$ & 92.2 & 87.3 & 90.7 & --* & 89.6 & 79.0 & 76.5 & --* & 84.9 & 0 & 8.8 & --* \\
\hline & $\chi$ & 0 & 0 & 0 & --* & 1.6 & 1.8 & 2.1 & --* & $<0.5$ & 9.6 & 18.1 & --* \\
\hline & $\beta$ & 0 & 0 & 0 & --* & 0 & 0 & 0 & --* & 0 & 2.5 & 3.9 & --* \\
\hline $20 \mathrm{Ni}$ & $\gamma^{\prime}$ & 86.9 & 89.0 & 87.8 & 64.1 & -- & -- & -- & 54.8 & 64.0 & 61.5 & 61.2 & 41.2 \\
\hline
\end{tabular}

*Not available due to the lack of the $\mathrm{V}$ element in the PanCo 2016 thermodynamic database

$\underline{\text { Microstructural evolution at } 1000 \sim 1100{ }^{\circ} \mathrm{C}}$

$1000{ }^{\circ} \mathrm{C}$ Figure 2 shows the typical microstructure of experimental alloys after aging at $1000{ }^{\circ} \mathrm{C}$ for $50 \sim 1000 \mathrm{~h}$. It is worthy to note that there was no precipitation of secondary phases in the baseline, $1 \mathrm{Mo}, 1 \mathrm{Nb}, 1 \mathrm{~V}$ and $20 \mathrm{Ni}$ alloys, as shown in Figures 2 (a), (c) $\sim$ (f). The $\gamma / \gamma^{\prime}$ microstructure of these alloys indicates that $\gamma^{\prime}$ precipitates were cuboidal after aging for $50 \mathrm{~h} . \gamma^{\prime}$ precipitates in the baseline alloy and $1 \mathrm{Mo}, 1 \mathrm{~V}$ and $20 \mathrm{Ni}$ alloys remained cuboidal (Figures 2 (a2) (a3), (c2) (c3), (e2) (e3) and (f2) (f3)), while the morphology of $\gamma^{\prime}$ phase in $4 \mathrm{Cr}$ and $1 \mathrm{Nb}$ alloys became rafted after aging for $500 \sim 1000 \mathrm{~h}$, as shown in Figures $2(\mathrm{~b} 2) \sim(\mathrm{b} 3)$ and $(\mathrm{d} 2) \sim(\mathrm{d} 3)$. In addition, plate-like secondary phases with gray-contrast and the blocky phase with black-contrast were observed in the $4 \mathrm{Cr}$ alloy after aging for 500 $\sim 1000 \mathrm{~h}$. The composition analyses indicated that the graycontrast phase was enriched in refractory alloying elements (W, $\mathrm{Nb}$ and $\mathrm{Ta}$ ) with depleted concentration of $\mathrm{Al}$, and it should be $\chi$ phase based on our previous study [6]. Meanwhile, the blackcontrast phase was enriched in $\mathrm{Al}$ and $\mathrm{Ti}$, therefore was considered to be $\beta$ phase.

Table III summarizes the volume fraction of various phases in experimental alloys after aging at $1000{ }^{\circ} \mathrm{C}$ for $50 \sim 1000 \mathrm{~h}$. It is worthy to note that volume fractions of $\gamma^{\prime}$ precipitates were at very high levels in the range of 81.3 to $92.2 \%$ for all these experimental alloys after aging for $50 \mathrm{~h}$. They remained at about $90 \%$ after aging for $1000 \mathrm{~h}$ in $1 \mathrm{~V}$ and $20 \mathrm{Ni}$ alloys, whereas $\gamma^{\prime}$ volume fraction in baseline, $1 \mathrm{Mo}$ and $1 \mathrm{Nb}$ alloys decreased to $61.1 \sim 72.5 \%$ when the prolonged heat treatment was employed. In the case of $4 \mathrm{Cr}$ alloy, $\gamma^{\prime}$ volume fraction was reduced significantly to about $40.3 \%$, the $\chi$ phase and $\beta$ phase co-existed with the volume fractions of $10.5 \%$ and $5.9 \%$, respectively, after aging for $1000 \mathrm{~h}$.

Table VI summarizes the size of $\gamma^{\prime}$ precipitates in four experimental alloys after aging at $1000{ }^{\circ} \mathrm{C}$ for $50 \sim 1000 \mathrm{~h}$. In baseline alloy, the size of $\gamma^{\prime}$ precipitates was $0.13 \mu \mathrm{m}$ after aging for $50 \mathrm{~h}$ and increased to $0.49 \mu \mathrm{m}$ when the prolonged heat treatment was employed for $1000 \mathrm{~h}$. Compared to the baseline alloy, Mo addition didn't change $\gamma^{\prime}$ size after aging from $50 \mathrm{~h}$ to $1000 \mathrm{~h}$. Moreover, additions of $\mathrm{V}$ and $\mathrm{Ni}$ resulted in the increase of $\gamma^{\prime}$ size compared with baseline and 1Mo alloys.

Table VI. Size of $\gamma^{\prime}$ Precipitates in Experimental Alloys after Aging at $1000^{\circ} \mathrm{C}$ for $50 \sim 1000 \mathrm{~h}, \mu \mathrm{m}$

\begin{tabular}{|c|c|c|c|}
\hline \multirow{2}{*}{ Alloys } & \multicolumn{3}{|c|}{ Aging time, $\mathrm{h}$} \\
\cline { 2 - 4 } & 50 & 500 & 1000 \\
\hline Baseline & $0.13 \pm 0.03$ & $0.37 \pm 0.09$ & $0.49 \pm 0.14$ \\
$1 \mathrm{Mo}$ & $0.13 \pm 0.03$ & $0.35 \pm 0.08$ & $0.44 \pm 0.11$ \\
$1 \mathrm{~V}$ & $0.30 \pm 0.25$ & $0.67 \pm 0.41$ & $0.86 \pm 0.48$ \\
$20 \mathrm{Ni}$ & $0.37 \pm 0.19$ & $0.63 \pm 0.32$ & $0.68 \pm 0.36$ \\
\hline
\end{tabular}

$1050{ }^{\circ} \mathrm{C}$ Figure 3 shows typical microstructural evolution of experimental alloys after aging for $50 \sim 1000 \mathrm{~h}$. $\gamma^{\prime}$ precipitates were found to be cuboidal in five experimental alloys after aging for $50 \mathrm{~h}$, as shown in Figures 3 (a1) $\sim(\mathrm{e} 1)$. Besides $\gamma$ and $\gamma^{\prime}$ primary phases, a significant amount of $\beta$ phase and a small amount of $\chi$ phase co-existed in the matrix of $4 \mathrm{Cr}$ alloy after aging for only $50 \mathrm{~h}$ (Figure 3 (b1)). In the matrix of $1 \mathrm{Nb}$ alloy, a graycontrast phase was found to envelop a bright-contrast phase after aging for $50 \mathrm{~h}$, as shown in Figure 3 (d1), whereas $\chi$ phase was observed in $1 \mathrm{~V}$ alloy (Figure $3(\mathrm{e} 1)$ ). According to our previous study [6], the gray-contrast phase and bright-contrast phase were considered to be $\chi$ phase and $\mu$ phase, respectively. The $\gamma^{\prime}$ phase in the baseline alloy became rafted when the prolonged heat treatment was employed (Figure 3 (a3)), and the same case occurred in $1 \mathrm{Mo}, 1 \mathrm{Nb}$ and $1 \mathrm{~V}$ alloys under the same aging condition, as shown in Figures 3 (c3) (e3). Moreover, the $\gamma^{\prime}$ phase in the $4 \mathrm{Cr}$ alloy was dissolved into the matrix completely after aging for $500 \mathrm{~h}$ (Figure 3 (b2)). In the $4 \mathrm{Cr}, 1 \mathrm{Mo}$ and $1 \mathrm{Nb}$ alloys, plate-like $\chi$ phase precipitated in the matrix after aging for $500 \sim 1000 \mathrm{~h}$ (Figures 3 (b2) (b3), (c2) (c3) and (d2) (d3)) and the $\beta$ phase was observed only in the $4 \mathrm{Cr}$ alloy. The volume fraction of blocky $\chi$ phase was enhanced by consuming the $\mu$ phase after $500 \sim 1000 \mathrm{~h}$ in the $1 \mathrm{Nb}$ alloy. 
Table III summarizes the volume fraction of various phases in five experimental alloys after aging at $1050{ }^{\circ} \mathrm{C}$ for $50 \sim 1000 \mathrm{~h}$. In the baseline alloy, the volume fraction of $\gamma^{\prime}$ precipitates was $79.5 \%$ after aging for $50 \mathrm{~h}$ and reduced to $63.2 \%$ for $1000 \mathrm{~h}$. Compared to the baseline alloy, a high volume fraction of $\gamma^{\prime}$ phase (about $90 \%$ ) was observed in $1 \mathrm{~V}$ alloy after aging for $50 \mathrm{~h}$, and it remained higher than $75 \%$ with the precipitation of $2.1 \% \chi$ phase after $1000 \mathrm{~h}$. The volume fraction of $\gamma^{\prime}$ precipitates in 1 Mo alloy after aging for $50 \mathrm{~h}$ was comparable to that of the baseline alloy, whereas a significant reduction of $\gamma^{\prime}$ volume fraction and $1.6 \% \chi$ phase were observed in $1 \mathrm{Mo}$ alloy after aging for $1000 \mathrm{~h}$. In the case of $1 \mathrm{Nb}$ alloy, the volume fraction of $\gamma^{\prime}$ precipitates was $74.5 \%$ after $50 \mathrm{~h}$ and reduced to $54.7 \%$ for $1000 \mathrm{~h}$. Besides the $\gamma^{\prime}$ phase, the volume fraction of $\chi$ phase increased to $5.3 \%$ after aging after $1000 \mathrm{~h}$. The volume fraction of $\gamma^{\prime}$ phase in $4 \mathrm{Cr}$ alloy decreased from $64.9 \%$ to 0 after aging from 50 to $1000 \mathrm{~h}$, while volume fractions of $\chi$ phase and $\beta$ phase increased to $14.7 \%$ and $6.9 \%$, respectively.

Base

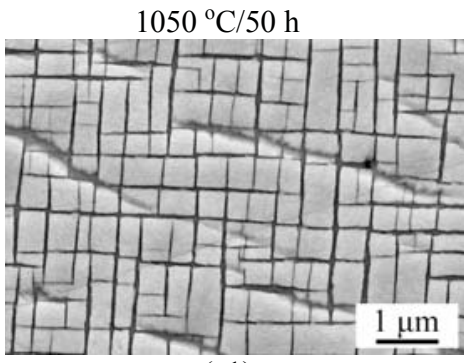

(a1)

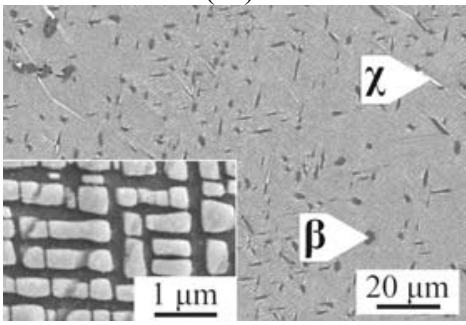

(b1)

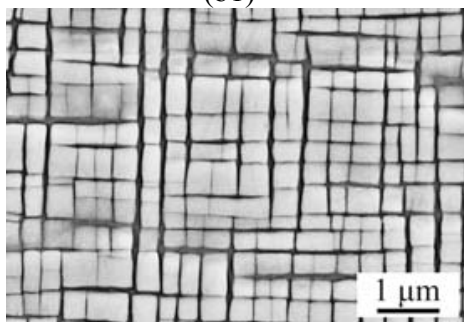

(c1)

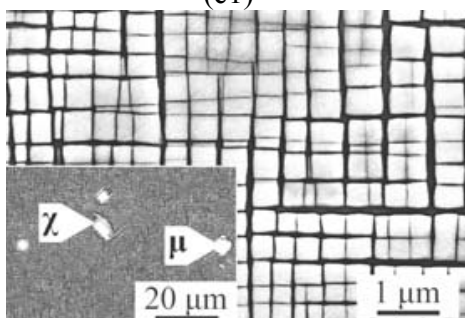

(d1)

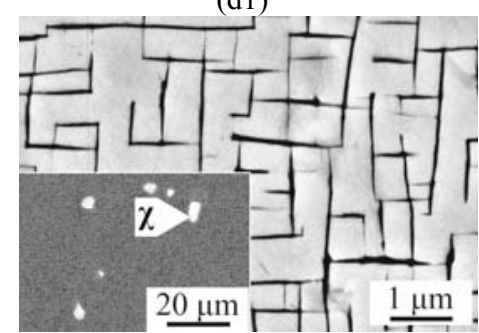

(e1)

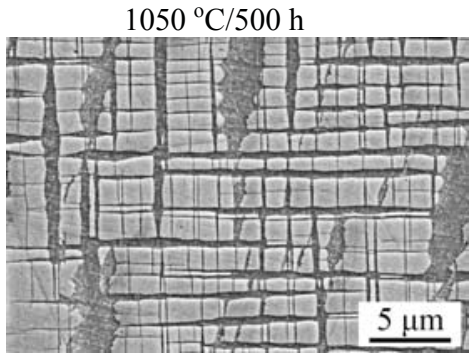

(a2)

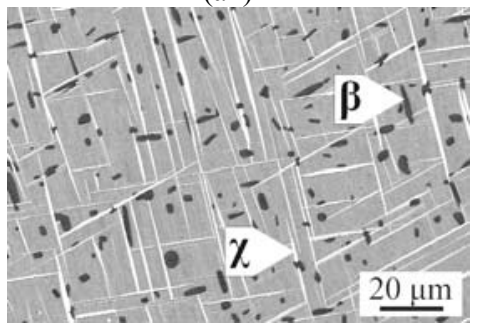

(b2)

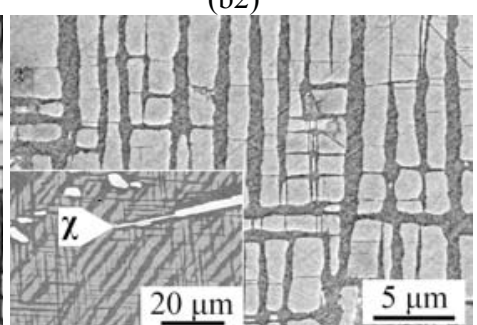

(c2)

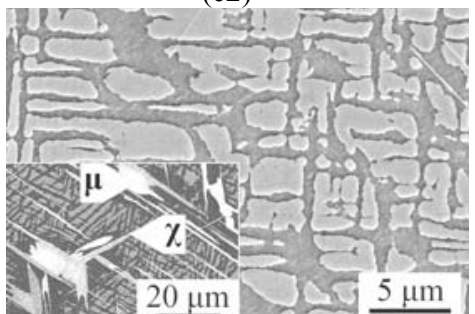

(d2)

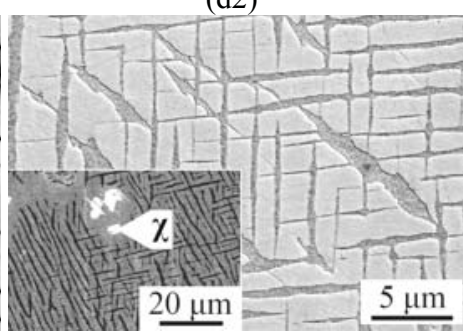

(e2)

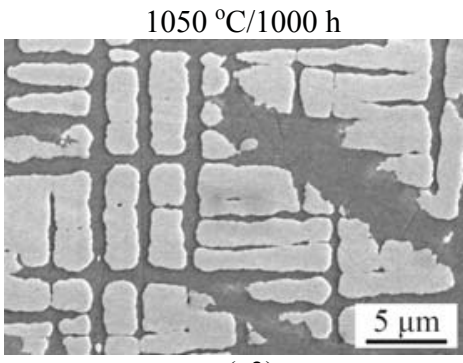

(a3)

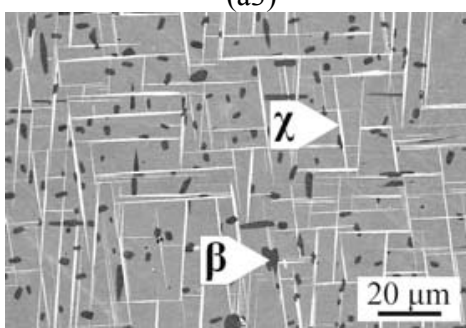

(b3)

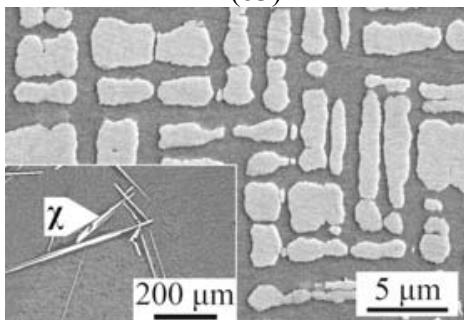

(c3)

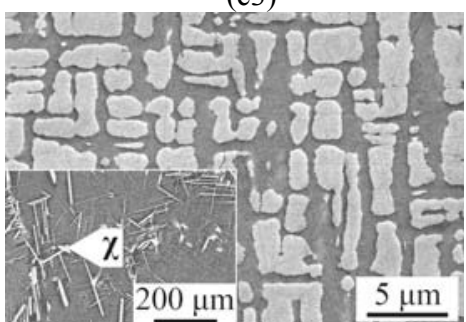

(d3)

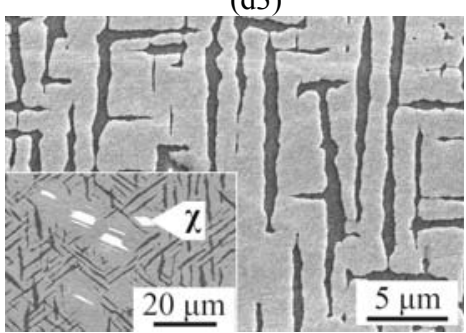

(e3)

Figure 3. Secondary electron images of etched samples showing the typical matrix microstructures of experimental alloys after heat treatment at $1050{ }^{\circ} \mathrm{C}$ for $50 \sim 1000 \mathrm{~h}$. 


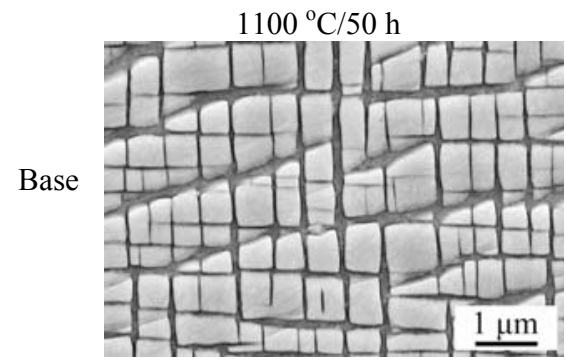

(a1)

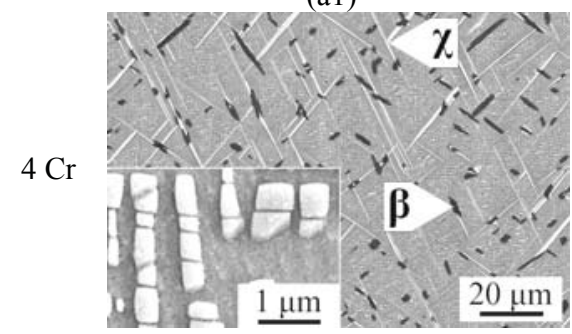

(b1)

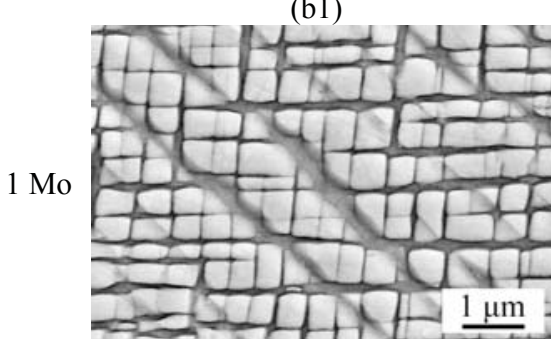

(c1)

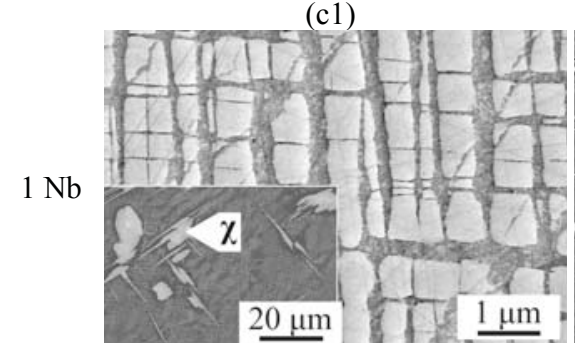

(d1)

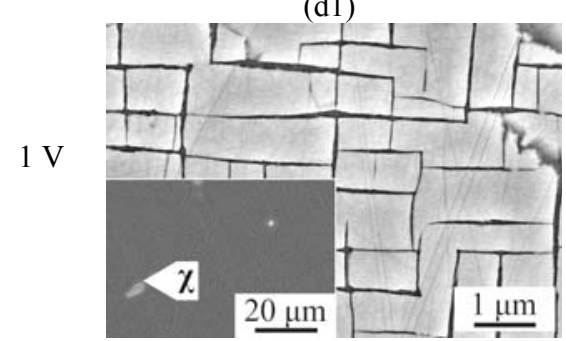

(e1)

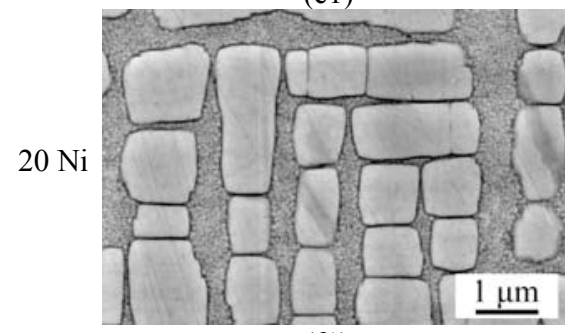

(f1)

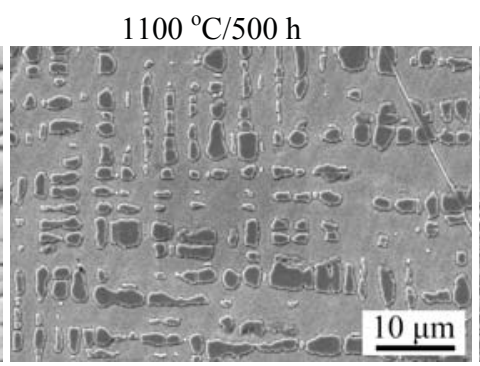

(a2)

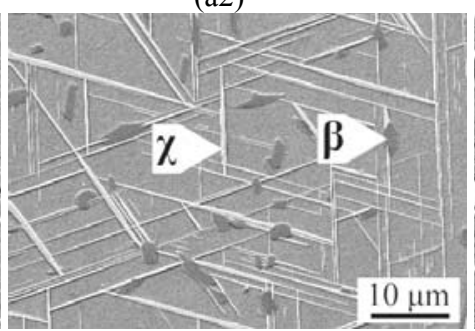

(b2)

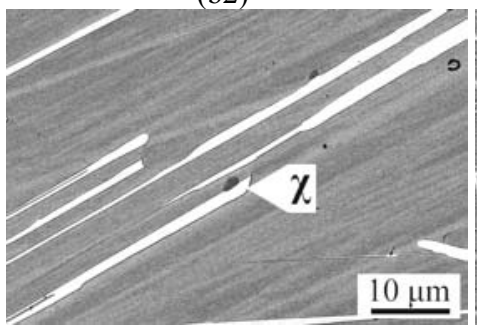

(c2)

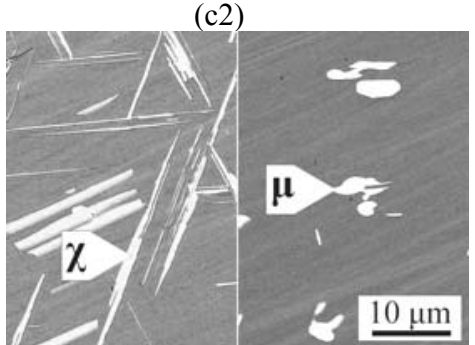

(d2)

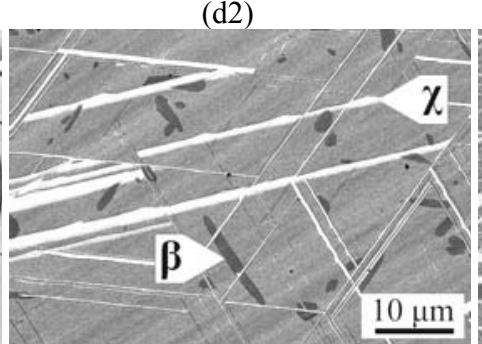

(e2)

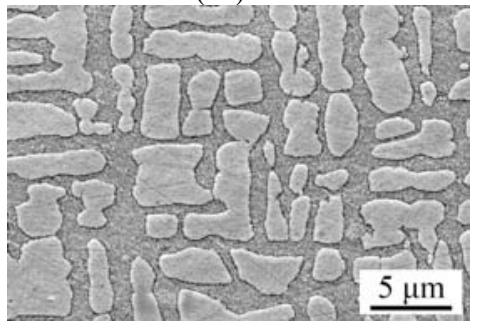

(f2)

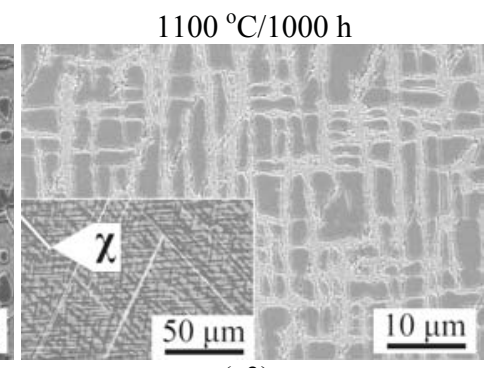

(a3)

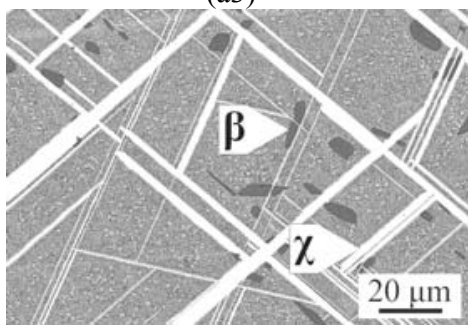

(b3)

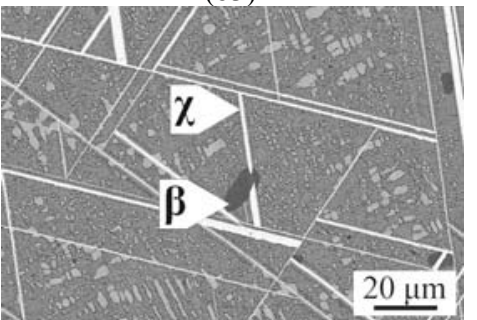

(c3)

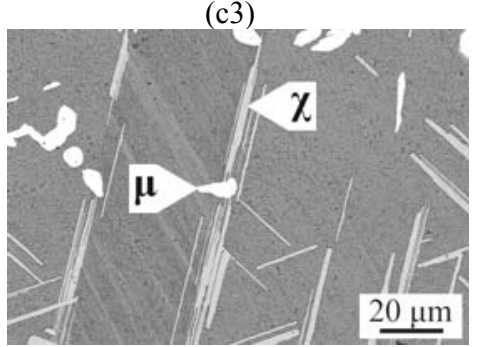

(d3)

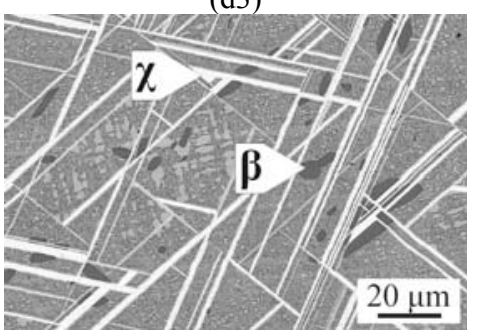

(e3)

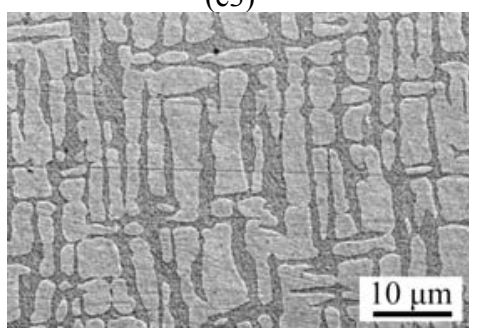

(f3)

Figure 4. Secondary electron images of etched samples showing the typical matrix microstructures of experimental alloys after heat treatment at $1100{ }^{\circ} \mathrm{C}$ for $50 \sim 1000 \mathrm{~h}$. 
$1100{ }^{\circ} \mathrm{C}$ Figure 4 shows the typical microstructural evolution of experimental alloys after aging at $1100{ }^{\circ} \mathrm{C}$ for $50 \sim 1000 \mathrm{~h}$. The $\gamma^{\prime}$ precipitates were found to be labyrinth in the $1 \mathrm{~V}$ alloy, and nearly cuboidal $\gamma^{\prime}$ precipitates were observed in the baseline, $4 \mathrm{Cr}, 1 \mathrm{Mo}$, $1 \mathrm{Nb}$ and $20 \mathrm{Ni}$ alloys after aging for $50 \mathrm{~h}$, as shown in Figures 4 (a1) $\sim(\mathrm{e} 1)$. There are no secondary phases in the baseline, $1 \mathrm{Mo}$ and $20 \mathrm{Ni}$ alloys, whereas the precipitation of $\beta, \chi$ and $\mu$ phases were found in the $4 \mathrm{Cr}, 1 \mathrm{Nb}$ and $1 \mathrm{~V}$ alloys. The significant amount of $\beta$ phase was observed only in the $4 \mathrm{Cr}$ alloy, while a limited amount of plate-like $\chi$ phase was found in $4 \mathrm{Cr}$ and $1 \mathrm{Nb}$ alloys. Blocky $\chi$ phase was also formed after aging for $50 \mathrm{~h}$ in the $1 \mathrm{Nb}$ and $1 \mathrm{~V}$ alloys. The rafting and dissolution of $\gamma^{\prime}$ precipitates occurred in the baseline and 20Ni alloys, whereas $\gamma^{\prime}$ precipitates in the $4 \mathrm{Cr}, 1 \mathrm{Mo}, 1 \mathrm{Nb}$ and $1 \mathrm{~V}$ alloys were dissolved into the matrix completely when the prolonged heat treatment was employed for $500 \mathrm{~h}$, as shown in Figures 4 (a2) (f2). In the $4 \mathrm{Cr}$ alloy, $\beta$ phase precipitated densely in the matrix after aging for $500 \mathrm{~h}$ (Figure 4 (b2)), and $\chi$ phase coarsened after aging for $1000 \mathrm{~h}$, as shown in Figure 4 (b3). In the $1 \mathrm{Mo}$ and $1 \mathrm{~V}$ alloys, $\chi$ phase was observed in the matrix, and the $\beta$ phase formed adjacent to $\chi$ phase after aging for $500 \mathrm{~h}$ (Figure 4 (c2) and (e2)). The density of $\chi$ phase and the size of $\beta$ phase particles increased after aging for $1000 \mathrm{~h}$ (Figure 4 (c3) and (e3)). The microstructural results clearly suggest that the additions of $\mathrm{V}$ and Mo promote the formation of $\chi$ phase significantly. However, it was found that the occurrence of $\beta$ phase was reduced with increasing Mo content but increased with $\mathrm{V}$ addition. Besides the plate-like $\chi$ phase with grey contrast precipitated in the matrix, the bright contrast $\mu$ phase was observed near grain boundary in the $1 \mathrm{Nb}$ alloy after aging for 500 $\sim 1000 \mathrm{~h}$, as shown in Figures $4(\mathrm{~d} 2) \sim(\mathrm{d} 3)$. It is interesting to note that the $\gamma^{\prime}$ phase was observed to re-precipitate in the baseline, $1 \mathrm{Mo}$ and $1 \mathrm{~V}$ alloys after $1000 \mathrm{~h}$ (Figures 4 (a3), (c3) and (e3)). The reason for this is currently unclear as is the existence of $\mu$ phase near grain boundaries in the $1 \mathrm{Nb}$ alloy (Figure $4(\mathrm{~d} 3)$ ).

Table V Size of $\gamma^{\prime}$ Precipitates in Experimental Alloys after Aging at $1000 \sim 1100{ }^{\circ} \mathrm{C}$ for $50 \mathrm{~h}, \mu \mathrm{m}$

\begin{tabular}{|c|c|c|c|}
\hline \multirow{2}{*}{ Alloys } & \multicolumn{3}{|c|}{ Aging temperature, ${ }^{\circ} \mathrm{C}$} \\
\cline { 2 - 4 } & 1000 & 1050 & 1100 \\
\hline Baseline & $0.13 \pm 0.03$ & $0.20 \pm 0.05$ & $0.23 \pm 0.06$ \\
$4 \mathrm{Cr}$ & $0.15 \pm 0.04$ & $0.17 \pm 0.03$ & $0.19 \pm 0.05$ \\
$1 \mathrm{Mo}$ & $0.13 \pm 0.03$ & $0.17 \pm 0.04$ & $0.20 \pm 0.04$ \\
$1 \mathrm{Nb}$ & $0.11 \pm 0.03$ & $0.16 \pm 0.04$ & $0.24 \pm 0.07$ \\
$1 \mathrm{~V}$ & $0.30 \pm 0.25$ & $0.32 \pm 0.11$ & $0.35 \pm 0.12$ \\
$20 \mathrm{Ni}$ & $0.37 \pm 0.19$ & $0.49 \pm 0.25$ & $0.57 \pm 0.23$ \\
\hline
\end{tabular}

As shown in Table III, the volume fraction of $\gamma^{\prime}$ phase in the baseline and $20 \mathrm{Ni}$ alloys remained $32.9 \%$ and $61.5 \%$, respectively, after aging at $1100{ }^{\circ} \mathrm{C}$ for $500 \mathrm{~h}$, although the $\gamma^{\prime}$ phase was completely dissolved in other experimental alloys. $\gamma^{\prime}$ phase volume fraction remained $61.2 \%$ in the $20 \mathrm{Ni}$ alloy after $1000 \mathrm{~h}$, whereas $66.5 \% \gamma^{\prime}$ phase existed in the baseline alloy. Compared to the baseline alloy, although a high volume fraction (about $85 \%$ ) of $\gamma^{\prime}$ phase was observed in the $1 \mathrm{~V}$ alloy after aging for $50 \mathrm{~h}$, there was only $8.8 \% \gamma^{\prime}$ phase with the co-existence of $18.1 \% \chi$ phase and $3.9 \% \beta$ phase after $1000 \mathrm{~h}$. Meanwhile, additions of $\mathrm{Mo}$ and $\mathrm{Nb}$ increased the volume fraction of $\chi$ phase after aging for $1000 \mathrm{~h}$, while the precipitation of $\beta$ phase was inhibited. Moreover, the precipitation of the $\chi$ and $\beta$ phases were promoted by the addition of $\mathrm{Cr}$.

Table V summarizes the size of $\gamma^{\prime}$ precipitates in four experimental alloys after aging at $1000 \sim 1100{ }^{\circ} \mathrm{C}$ for $50 \mathrm{~h}$. In the baseline alloy, the size of $\gamma^{\prime}$ precipitates was $0.13 \mu \mathrm{m}$ after aging at $1000{ }^{\circ} \mathrm{C}$ and increased to $0.23 \mu \mathrm{m}$ after $50 \mathrm{~h}$ at $1100{ }^{\circ} \mathrm{C}$. Compared to the baseline alloy, $\mathrm{Cr}$, Mo and $\mathrm{Nb}$ additions did not noticeably change the $\gamma^{\prime}$ size in the temperature range of $1000 \sim$ $1100{ }^{\circ} \mathrm{C}$, while additions of $\mathrm{V}$ and $\mathrm{Ni}$ resulted in the significant increase of $\gamma^{\prime}$ size.

\section{$\underline{\text { Calculation of } \gamma^{\prime} \text { solvus temperatures and phase equilibria }}$}

Figure 5 shows $\gamma^{\prime}$ solvus temperatures of the baseline, $4 \mathrm{Cr}$, $1 \mathrm{Mo}$, $1 \mathrm{Nb}$ and $20 \mathrm{Ni}$ alloys that were predicted by the Pandat software. The data in $1 \mathrm{~V}$ alloy was not calculated due to the absence of $\mathrm{V}$ in the current database of Co-base alloys. The $\gamma^{\prime}$ solvus temperatures that were determined by DSC are shown in the same figure for comparison. Based on the computational data, it is clear that the additions of $\mathrm{Cr}$ and Mo decreased $\gamma^{\prime}$ solvus temperature by about 40 and $20^{\circ} \mathrm{C}$, respectively, while a slight influence of $\mathrm{Nb}$ addition was present and the $\mathrm{Ni}$ addition increased the solvus temperature of $\gamma^{\prime}$ phase considerably. However, a slight negative influence of $\mathrm{Mo}$ and $\mathrm{Nb}$ additions was present in the experimental data, although the $\mathrm{Cr}$ addition resulted in a significant reduction of the $\gamma^{\prime}$ solvus temperature. Moreover, the strong positive influence due to the Ni addition in the experimental data was observed as the prediction.

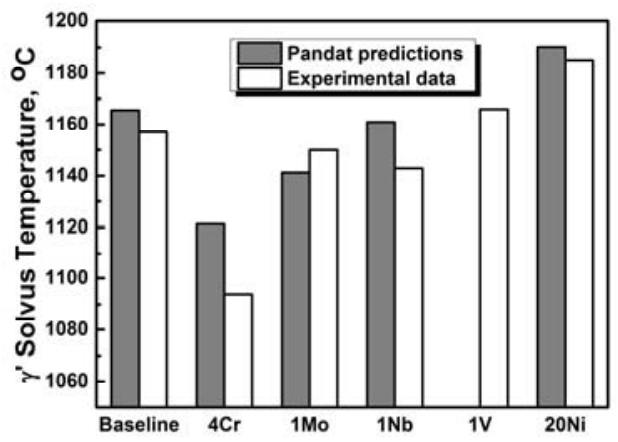

Figure 5. Computational and experimental data of $\gamma^{\prime}$ solvus temperature.

The equilibrium volume fractions of various phases at $1000 \sim$ $1100{ }^{\circ} \mathrm{C}$ in experimental alloys were calculated using the Pandat software and are summarized in Table III. The occurrence of $\gamma+\gamma^{\prime}$ phases were predicted in all experimental alloys. However, there was a noticeable disagreement with experimental observations that were carried out after $1000 \mathrm{~h}$ exposures. Although the predicted $\gamma^{\prime}$ volume fractions in the baseline, $1 \mathrm{Mo}$ and $1 \mathrm{Nb}$ alloys were closer to the experimental data at 1000 and $1050{ }^{\circ} \mathrm{C}$, significant discrepancies were evident at $1100{ }^{\circ} \mathrm{C}$ in all experimental alloys as well as at lower temperatures in the $4 \mathrm{Cr}$ and $20 \mathrm{Ni}$ alloys.

$\underline{\text { Hardness and elastic modulus of } \gamma^{\prime} \text { precipitates }}$

The average hardness and elastic modulus of the $\gamma^{\prime}$ phase in experimental alloys are shown in Figure 6. It is clear that the hardness of the $\gamma^{\prime}$ phase was increased by the additions of $\mathrm{Mo}, \mathrm{Nb}$, $\mathrm{V}$ and $\mathrm{Ni}$. The rank in terms of $\gamma^{\prime}$ hardening is $\mathrm{V}>\mathrm{Nb}>\mathrm{Mo} \approx \mathrm{Ni}$. In contrast, $\mathrm{Cr}$ addition was found to decrease $\gamma^{\prime}$ hardness more distinctively, compared to the baseline alloy. On the other hand, the variation trend of the $\gamma^{\prime}$ phase elastic modulus was nearly the same as that for the hardness of the $\gamma^{\prime}$ phase. However, the $\mathrm{V}$ addition did not change the elastic modulus of the $\gamma^{\prime}$ phase. 


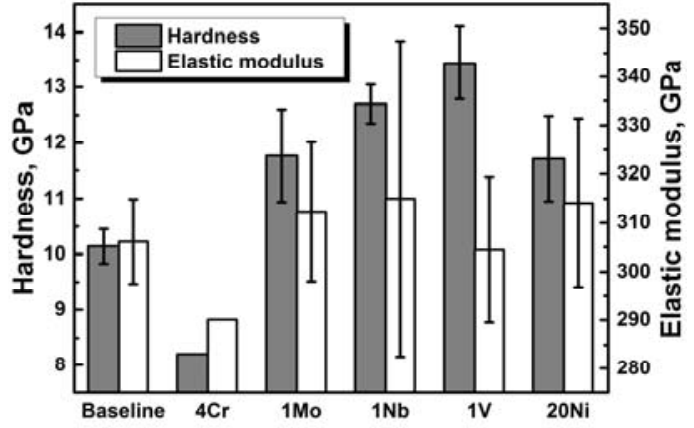

Figure 6. Elastic modulus and hardness of $\gamma^{\prime}$ phase in experimental alloys, determined by nano-indentation.

\section{Discussion}

To achieve desired high-temperature properties under extremely severe conditions, more than ten alloying elements have been introduced into advanced multi-component $\mathrm{Ni}$-base superalloys for alloy development [1, 3]. However, complex chemical compositions might lead to the existence of secondary phases, with reduced microstructural stability and mechanical behavior [1]. Thus, the relationship of alloy chemistry and microstructural stability is of primary importance to assure an optimum combination of properties. Moreover, in order to reduce the life cycle of alloy design, the application of computational materials has received more attention. Thus, it is necessary to investigate the effects of alloying elements on $\gamma^{\prime}$ solvus temperature, phase equilibria, $\gamma^{\prime}$ hardness as well as the consistency between experimental and computational data.

\section{$\underline{y^{\prime} \text { solvus temperatures }}$}

Increasing the $\gamma^{\prime}$ solvus temperature is essential for the development of Co-base superalloys, which achieve the required material properties for high temperature applications. Recent investigations indicated that the additions of $\mathrm{Cr}$, Mo and $\mathrm{V}$ reduced the $\gamma^{\prime}$ solvus temperature, whereas a positive influence of $\mathrm{Mo}, \mathrm{V}, \mathrm{Nb}$ and $\mathrm{Ni}$ additions was also reported [6, 9, 15]. The possible explanation for the controversial effects of Mo and $\mathrm{V}$ on $\gamma^{\prime}$ solvus temperature may be due to the different content of $\gamma^{\prime}$ forming elements in alloy chemistry, such as W. For example, Mo additions supplemented refractory alloying elements in Co-Al-Wbase alloys and would increase the $\gamma^{\prime}$ solvus temperature if the content of refractory alloying elements was under-saturated before the addition of Mo [9]. In the case of alloys containing saturated refractory alloying elements, excessive additions of Mo could promote the precipitation of secondary phases, which would consume refractory alloying elements, resulting in the reduction of $\gamma^{\prime}$ forming elements in the $\gamma^{\prime}$ phase and finally decreasing $\gamma^{\prime}$ solvus temperature $[6,15]$. Similarly, the $\mathrm{V}$ addition increased the $\gamma^{\prime}$ solvus temperature in $\mathrm{Co}-9$ at.\%Al-7 at.\%W alloy [9], but decreased that in Co-9 at.\%Al-10 at.\%W alloy [6]. In the present study, the precipitation of $\chi$ phase suggested that $\gamma^{\prime}$ forming elements in the baseline alloy were saturated at $1100{ }^{\circ} \mathrm{C}$ (Figure 4 (a3)). Thus, the additions of $\mathrm{Nb}$ and $\mathrm{Mo}$, as $\gamma^{\prime}$ forming elements, increased the precipitation of secondary phases and decreased the $\gamma^{\prime}$ solvus temperature. On the other hand, the $\mathrm{Cr}$ addition decreased the $\gamma^{\prime}$ solvus temperature as it is a $\gamma$ forming element. Meanwhile, the addition of Ni enlarged the $\gamma+\gamma^{\prime}$ two-phase region [11] and resulted in the dissolution of $\gamma^{\prime}$ forming elements into $\gamma+\gamma^{\prime}$ matrix. Therefore, the $\gamma^{\prime}$ solvus temperature in 20Ni alloy was higher than that in the baseline alloy. It was found that the $\mathrm{V}$ addition did not increase $\gamma^{\prime}$ solvus temperature significantly.

Predicted values from the Pandat software revealed the positive effect of $\mathrm{Ni}$ additions on $\gamma^{\prime}$ solvus temperatures while the additions of $\mathrm{Cr}$, Mo and $\mathrm{Nb}$ decreased $\gamma^{\prime}$ solvus temperatures, and they are in agreement with our experimental data as shown in Figure 5. However, the predicted phase transformation temperatures were higher than the current experimental data, especially for $4 \mathrm{Cr}, 1 \mathrm{Nb}$ and $20 \mathrm{Ni}$ alloys. These differences may arise as the Pandat software predicts the $\gamma+\gamma^{\prime}$ phase field to be larger than that found from experimental studies and does not accurately predict the precipitation of secondary phases, which consumes $\gamma^{\prime}$ forming elements such as $\mathrm{W}, \mathrm{Mo}, \mathrm{Nb}$ and $\mathrm{V}$. Consequently, the predicted values for $\gamma^{\prime}$ solvus temperature are higher than the measured values.

\section{$\underline{\text { Phase equilibria at } 1000 \sim 1100{ }^{\circ} \mathrm{C}}$}

Recent studies have indicated that the $\gamma+\gamma^{\prime}$ two phase region is very narrow and secondary phases such as $\mu, \chi$ and $\beta$ phases could precipitate after long-term heat treatment $[4,6,11]$. The investigation by Shinagawa et al. indicated that $\mathrm{Ni}$ addition exhibited a positive effect on enlarging the $\gamma+\gamma^{\prime}$ two-phase region [11]. Moreover, the investigation by Xue et al. suggested that the additions of $\mathrm{Mo}, \mathrm{Nb}$ and $\mathrm{Ta}$ promoted the precipitation of $\chi$ phase in Co-Al-W-base alloys at $900{ }^{\circ} \mathrm{C}[6]$. According to the research of Yan et al., lower $\mathrm{Cr}$ level $(<10$ at.\%) could increase the propensity for the precipitation of $\chi$ phase and $\beta$ phase in Co-AlW-base alloys, whereas $\mu$ phase precipitated instead of $\chi$ phase and $\beta$ phase in alloys with large amounts ( 20 at.\%) of $\mathrm{Cr}$ at 700 $\sim 770{ }^{\circ} \mathrm{C}$ [5]. In the current study, the $\gamma / \gamma^{\prime}$ two-phase microstructure was observed in all experimental alloys after heat treatment at $1000{ }^{\circ} \mathrm{C}$ for $1000 \mathrm{~h}$, coupled with $\beta$ phase and $\chi$ phase only in $4 \mathrm{Cr}$ alloy. When the aging temperature was elevated, the $\gamma+\gamma^{\prime}$ two-phase region was reduced and eventually disappeared, while $\beta$ phase and $\chi$ phase formed in the matrix of the $4 \mathrm{Cr}, 1 \mathrm{Mo}$ and $1 \mathrm{~V}$ alloys. The $\chi$ phase in the matrix and $\mu$ phase near the grain boundary were observed in the $1 \mathrm{Nb}$ alloy after aging at 1100 ${ }^{\circ} \mathrm{C}$, whereas almost no precipitation of secondary phases occurred in the baseline and 20Ni alloys.

The reason for the precipitation of secondary phases was mainly associated with the over-saturation of alloying elements in the matrix at the specified temperatures, such as $\mathrm{Nb}$, Mo and $\mathrm{V}$, resulted in the promotion of $\chi$ phase formation at $1100{ }^{\circ} \mathrm{C}$. Our previous research revealed that $\mu$ phase was formed in the matrix during solution treatment, and gradually transformed into blocky $\chi$ phase during aging treatment at $900{ }^{\circ} \mathrm{C}$ in Co-9 at.\%Al-10 at.\% $\mathrm{W}$-base quarternary alloys containing $\mathrm{Nb}$, Mo and $\mathrm{V}$, respectively [6]. In the current study, the same behavior occurred with limited amounts of blocky $\chi$ phase in the $1 \mathrm{Mo}, 1 \mathrm{Nb}$ and $1 \mathrm{~V}$ alloys during aging at $1000{ }^{\circ} \mathrm{C} \sim 1100{ }^{\circ} \mathrm{C}$. Meanwhile, limited amounts of blocky $\chi$ phase and a modest amount of plate-like $\chi$ phase precipitated by consuming $\gamma^{\prime}$ forming elements, such as Ta, W, $\mathrm{Mo}, \mathrm{Nb}$ and $\mathrm{V}$, resulted in the $\gamma$ matrix adjacent to $\chi$ phase. With increasing aging temperature, alloying additions of $\mathrm{Cr}, \mathrm{Nb}, \mathrm{V}$ and Mo promoted $\chi$ phase formation (Figures 4 (b3) (e3) and Table III). The $\beta$ phase was also observed to precipitate adjacent to $\chi$ phase (Figures 4 (b3), (c3) and (e3)). It is suggested that $\beta$ phase formation was promoted by alloying additions of $\mathrm{Cr}$ and $\mathrm{V}$, the propensity for $\beta$ phase is greater in the $4 \mathrm{Cr}$ alloy compared to the $1 \mathrm{~V}$ alloy. Conversely, the precipitation of $\beta$ phase was found to be 
reduced by the additions of Mo and $\mathrm{Nb}$ (Table III). Moreover, $\mathrm{Ni}$ addition improved the stability of $\gamma^{\prime}$ phase and retained the $\gamma+\gamma^{\prime}$ two-phase microstructure after aging at $1000{ }^{\circ} \mathrm{C}$ and $1100{ }^{\circ} \mathrm{C}$ in this study.

The comparison of predicted and experimental phase equilibria reveal that the predicted composition range of the $\gamma+\gamma^{\prime}$ two-phase region in computational phase equilibria was larger than that found in experimental studies (Table III). It is worthy to note that the predicted effects of alloying elements, such as Ta, Ti, Mo and $\mathrm{Nb}$, on phase equilibria were relatively accurate, whereas some deviations were observed in the predicted effects of $\mathrm{Cr}$ and $\mathrm{Ni}$ on phase equilibria, as shown in Table III. Addition of $\mathrm{V}$ could also enlarge the $\gamma+\gamma^{\prime}$ two-phase region, although this element is not available in the PanCo 2016 thermodynamic database for Co-base alloys. Compared to the predicted phase equilibria at $1000 \sim 1050$ ${ }^{\circ} \mathrm{C}$, larger deviations were found in the predicted phase equilibria at $1100{ }^{\circ} \mathrm{C}$ in Co-base alloys, for the possible reason that less study has been focused on phase equilibria at higher temperature, especially at $1100{ }^{\circ} \mathrm{C}$, resulting in less data for the thermodynamics database. It is necessary to optimize the database of Co-base alloys based on the experimental effects of alloying elements, such as $\mathrm{Cr}$ and $\mathrm{Ni}$, as well as experimental phase equilibria at higher temperatures. Moreover, the additions of alloying elements must be carefully optimized, based on the combination of experiments and computational design, in order to generate $\gamma / \gamma^{\prime}$ two-phase alloys and avoid the possible precipitation of secondary phases.

\section{Hardness and elastic modulus of $\gamma^{\prime}$ precipitates}

Recent studies have indicated that high volume fraction of $\gamma^{\prime}$ phase resulted in outstanding creep resistance of both polycrystalline [20] and single crystal Co-base superalloys [7, 13]. In addition, our previous studies revealed that the formation of stacking faults (SF) and antiphase boundaries (APB) in the $\gamma^{\prime}$ phase, as well as the rafting of the $\gamma^{\prime}$ phase with positive $\gamma / \gamma^{\prime}$ misfit, could decrease the creep rate of Co-base superalloys with high volume fractions of $\gamma^{\prime}$ phase [13]. However, not only $\gamma^{\prime}$ volume fraction but also $\gamma^{\prime}$ phase stability and its resistance against strain strongly influences high temperature performance of alloys [12]. Using an atomic force microscope (AFM) technique, local nanoindentation tests have been conducted on individual $\gamma^{\prime}$ precipitates of Ni-base [16, 17] and Co-base [18] superalloys. Most recently, Povstugar et al. [18] reported that Ta was a very efficient $\gamma^{\prime}$ strengthening element, for the reason that the substitution of $\mathrm{W}$ by $\mathrm{Ta}$ in $\mathrm{Co}_{3}(\mathrm{Al}, \mathrm{W})$ lattice led to a significant increase in superlattice intrinsic stacking fault energy as well as $\gamma^{\prime}$ phase hardness. Meanwhile, $\gamma^{\prime}$ hardness values of $9.6 \sim 10.4 \mathrm{GPa}$ were experimentally determined for a Co-Al-W-Ta-Ti alloy, and they were very close to that of the baseline alloy in this study. Applying supercell models, Chen et al. calculated that Mo and Ta preferred the $\mathrm{W}$ sites in the $\mathrm{Co}_{3}(\mathrm{Al}, \mathrm{W})$ lattice and could stabilize the $\gamma^{\prime}$ phase [23]. $\mathrm{Nb}$ and $\mathrm{V}$ were also proved to be $\gamma^{\prime}$ forming elements in Co-base alloys (occupying B-sites of the $\mathrm{A}_{3} \mathrm{~B}$ ordered phase), whereas $\mathrm{Cr}$ is a $\gamma$ forming element [5, 9]. These characteristics could be the reason for the higher hardness of the $\gamma^{\prime}$ phase in the $1 \mathrm{Mo}, 1 \mathrm{Nb}$ and $1 \mathrm{~V}$ alloys, as well as the lower hardness in the $4 \mathrm{Cr}$ alloy, compared with that of the baseline alloy in the current research. Although Ni is not a $\gamma^{\prime}$ forming element, $\mathrm{Ni}$ addition exhibited a strong positive effect on enlarging the $\gamma+\gamma^{\prime}$ two-phase region in Co-base alloys $[11,25]$. Ni additions resulted in the dissolution of $\gamma^{\prime}$ forming elements in the $\gamma+\gamma^{\prime}$ phase field, and increased the hardness of the $\gamma^{\prime}$ phase.

Unlike $\gamma^{\prime}$ phase hardness, the elastic modulus of the $\gamma^{\prime}$ phase in the present study is not in good agreement with the literatures by Tanaka et al. [24] and Povstugar et al. [18], which were in the range of $220 \mathrm{GPa}$ and $260 \mathrm{GPa}$. Their measurements were carried out by using AFM instead of the nano-indentation technique that was used in this study, which could be one of the reasons for such a discrepancy in elastic modulus. By using the Oliver-Pharr method [19], the elastic modulus was determined by the slope of the force-depth curve during the recovery stage of elastic deformation. The recovery of elastic deformation in the $\gamma$ phase adjacent to the $\gamma^{\prime}$ phase could also affect the results. Therefore, the relatively high elastic modulus values that have been generated in this study could be influenced by the $\gamma / \gamma^{\prime}$ interface, such as the misfit stress, or the surrounding phases.

\section{Conclusions}

The influence of alloying elements on $\gamma^{\prime}$ solvus temperature, microstructural evolution and phase equilibria as well as $\gamma^{\prime}$ phase hardness after aging treatment were investigated in Co-Al-W-TaTi-base alloys in the temperature range of $1000{ }^{\circ} \mathrm{C}$ and $1100{ }^{\circ} \mathrm{C}$ for $50 \mathrm{~h} \sim 1000 \mathrm{~h}$. The following conclusions can be drawn:

1. Compared with the baseline alloy, $\mathrm{Ni}$ and $\mathrm{V}$ additions were found to promote $\gamma^{\prime}$ stability by increasing the $\gamma^{\prime}$ solvus temperature. The 20 at. $\% \mathrm{Ni}$ addition was more potent than the 1 at.\% $\mathrm{V}$ addition. Contrarily, $\mathrm{Cr}$, Mo and $\mathrm{Nb}$ additions presented a negative effect on $\gamma^{\prime}$ solvus temperature in the order: $\mathrm{Cr}>\mathrm{Nb}>\mathrm{Mo}$.

2. The composition of the baseline alloy resided in the $\gamma+\gamma^{\prime}$ equilibrium phase field at $1000 \sim 1050{ }^{\circ} \mathrm{C}$, but lied in the $\gamma+\gamma^{\prime}+\chi$ phase region at $1100{ }^{\circ} \mathrm{C}$. Ni addition enlarged the $\gamma+\gamma^{\prime}$ two phase region significantly. Additions of $\mathrm{Cr}$, Mo and $\mathrm{V}$ promoted the precipitation of secondary phases, and the compositions of $4 \mathrm{Cr}, 1 \mathrm{Mo}$ and $1 \mathrm{~V}$ alloys were located in the $\gamma+\gamma^{\prime}+\chi+\beta$ equilibrium phase field at $1100{ }^{\circ} \mathrm{C}$, while the $1 \mathrm{Nb}$ alloy was located in the $\gamma+\chi+\mu$ equilibrium phase field.

3. There were some differences between predicted and experimental $\gamma^{\prime}$ solvus temperature and $\gamma^{\prime}$ volume fraction values, but the trends were generally the same. Meanwhile, the calculated $\gamma+\gamma^{\prime}$ equilibrium phase regions were generally larger compared with the experimental data. Using experimental data such as those presented here, further modification of the Pandat thermodynamic database could be undertaken to improve the accuracy of phase diagram modeling for these Co-base alloys.

4. The hardness of the $\gamma^{\prime}$ phase was promoted by alloying additions in the following order: $\mathrm{V}>\mathrm{Nb}>\mathrm{Mo} \approx \mathrm{Ni}$; while $\mathrm{Cr}$ addition exhibited a strong negative effect on $\gamma^{\prime}$ hardness, compared with the baseline alloy,

\section{Acknowledgments}

This work was financially supported by the National Natural Science Foundation of China (Grant Nos. 50771012, 51201006 and 51301014) and the Aeronautical Science Foundation of China (Grant No. 2009ZF74011). The authors are very grateful to X.N. 
Zhang, J. Zhao and C.P. Liu for their contribution during the investigation of nano-indentation, as well as F. Zhang and J. Zhang for their investigation of predicted data by Pandat software.

\section{References}

1. R.C. Reed, The Superalloys: Fundamentals and Applications (New York: Cambridge University Press, 2006).

2. T.M. Pollock and S. Tin, "Nickel-Based Superalloys for Advanced Turbine Engines: Chemistry, Microstructure, and Properties," Journal of Propulsion and Power, 22 (2) (2006), 361374.

3. C.T. Sims, N.S. Stoloff, and W.C. Hagel. Superalloys II (New York, NY: Wiley, 1987).

4. J. Sato, et al., "Cobalt-Base High-Temperature Alloys," Science, 312 (5770) (2006), 90-91.

5. H.Y. Yan, V.A. Vorontsov, and D. Dye, "Alloying Effects in Polycrystalline $\gamma^{\prime}$ Strengthened Co-Al-W Base Alloys," Intermetallics, 48 (2014), 44-53.

6. F. Xue, M.L. Wang, and Q. Feng, "Alloying Effects on HeatTreated Microstructure in Co-Al-W-Base Superalloys at $1300^{\circ} \mathrm{C}$ and $900^{\circ}$ C," Superalloys 2012, (2012), ed. E.S. Huron et al (Warrendale, PA: The Minerals, Metals and Materials Society, 2012), 813-821.

7. M.S. Titus, A. Suzuki, and T.M. Pollock, "Creep and Directional Coarsening in Single Crystals of New $\gamma-\gamma^{\prime}$ CobaltBase Alloys," Scripta Materialia, 66 (8) (2012), 574-577.

8. K. Tanaka et al. "Morphology Change of $\gamma^{\prime}$ Precipitates in $\gamma / \gamma^{\prime}$ Two-Phase Microstructure in Co-Based Superalloys by HigherOrder Alloying" (Paper presented at the MRS Proceedings 2011, New York, 2010), 423-428.

9. M. Ooshima M et al. "Effects of Quaternary Alloying Elements on the $\gamma^{\prime}$ Solvus Temperature of Co-Al-W Based Alloys with FCC/L1 $1_{2}$ Two-Phase Microstructures," Journal of Alloys and Compounds, 508 (1) (2010), 71-78.

10. A. Suzuki, and T.M. Pollock. "High-Temperature Strength and Deformation of $\gamma / \gamma^{\prime}$ Two-Phase Co-Al-W-Base Alloys," Acta Materialia, 56 (6) (2008), 1288-1297.

11. K. Shinagawa et al. "Phase Equilibria and Microstructure on $\gamma^{\prime}$ Phase in Co-Ni-Al-W System," Materials Transactions, 49 (6) (2008), 1474-1479.

12. F. Xue et al. "Creep Behavior in a $\gamma^{\prime}$ Strengthened Co-Al-WTa-Ti Single-Crystal Alloy at $1000{ }^{\circ} \mathrm{C}$," Scripta Materialia, 97 (2015), 37-40.

13. F. Xue, H.J. Zhou, and Q. Feng, "Improved High-Temperature Microstructural Stability and Creep Property of Novel Co-Base Single-Crystal Alloys Containing Ta and Ti," JOM, 66 (12) (2014), 2486-2494.
14. F. Xue et al. "Improved High Temperature $\gamma^{\prime}$ Stability of CoAl-W-Base Alloys Containing Ti and Ta," Materials Letters, 112 (0) (2013), 215-218.

15. A. Bauer et al. "Microstructure and Creep Strength of Different $\gamma / \gamma$ '-Strengthened Co-Base Superalloy Variants," Scripta Materialia, 63 (12) (2010), 1197-1200.

16. T. Schöberl, H.S. Gupta, and P. Fratzl, "Measurements of Mechanical Properties in Ni-base Superalloys Using Nanoindentation and Atomic Force Microscopy," Materials Science and Engineering A, 363 (s 1-2) (2003), 211-220.

17. M. Göken, and M. Kempf, "Microstructural Properties of Superalloys Investigated by Nanoindentations in an Atomic Force Microscope," Acta Materialia, 47 (3) (1999), 1043-1052.

18. I. Povstugar et al. "Elemental Partitioning and Mechanical Properties of Ti- and Ta-Containing Co-Al-W-Base Superalloys Studied by Atom Probe Tomography and Nanoindentation," Acta Materialia, 78 (2014), 78-85.

19. Oliver et al. "Improved Technique for Determining Hardness and Elastic Modulus Using Load and Displacement Sensing Indentation Experiments," Journal of Materials Research Home, 7 (06) (1992), 1564-1583.

20. A. Bauer et al. "Creep Properties of Different $\gamma^{\prime}$-Strengthened Co-Base Superalloys," Materials Science and Engineering: A, 550 (0) (2012), 333-341.

21. Y.J. Guo, D.H. Zhang, "Application of Point Count Method on the Fraction Measurement of Ferritic in Subcritical Quenched 45 Steel," Journal of Nanchang University (Engineering \& Technology), 1 (1983), 49-55

22. X. Li, B. Bhushan. "A Review of Nanoindentation Continuous Stiffness Measurement Technique and its Applications," Materials Characterization, 48 (1) (2002), 11-36

23. M. Chen, and C. Wang, "First-Principles Investigation of the Site Preference and Alloying Effect of Mo, Ta and Platinum Group Metals in $\gamma^{\prime}-\mathrm{Co}_{3}(\mathrm{Al}, \mathrm{W}), "$ Scripta Materialia, 60 (8) (2009), 659-662.

24. K. Tanaka et al. "Single-Crystal Elastic Constants of $\mathrm{Co}_{3}(\mathrm{Al}, \mathrm{W})$ with the $\mathrm{L}_{2}$ Structure," Applied Physics Letters, 91 (18) (2007), 181907-181903.

25. F. Xue et al. "Effects of Ni on Microstructural Evolution and $\gamma^{\prime}$ Dissolution of Novel Co-Al-W Base Alloys," Acta Metallurgica Sinica, 50 (7) (2014), 845-853. 